\title{
Antioxidant Activities and Anticancer Cell Proliferation Properties of Wild Strawberries
}

\author{
Shiow Y. Wang ${ }^{1}$ and Kim S. Lewers \\ U.S. Department of Agriculture, Agricultural Research Service, Beltsville Agricultural Research Center, \\ Fruit Laboratory, Bldg. 010A, BARC-West, 10300 Baltimore Avenue, Beltsville, MD 20705-2350 \\ Linda Bowman and Min Ding \\ Pathology and Physiology Research Branch, Health Effects Laboratory Division, National Institute \\ for Occupational Safety and Health, 1095 Willowdale Road, Morgantown, WV 26505
}

\begin{abstract}
Additional Index words. Fragaria, germplasm, anthocyanin, phenolics, free radicals
Abstract. Fruit extracts from 17 to 18 representatives of three strawberry species [Fragaria virginiana Mill., $F$. chiloensis (L.) Mill., and $F$. $\times$ ananassa Duchesne ex Rozier] were tested for the ability to inhibit proliferation of A549 human lung epithelial cancer cells. The fruit extracts also were tested for activities against free radicals, (peroxyl radicals, hydroxyl radicals, singlet oxygen, and superoxide radicals), the activities of antioxidant enzymes Iglutathione peroxidase (EC 1.11.1.9), superoxide dismutase (EC 1.15.1.1), guaiacol peroxidase (EC 1.11.1.7), ascorbate peroxidase (EC 1.11.1.11), monodehydroascorbate reductase (EC 1.6.5.4), dehydroascorbate reductase (EC 1.8.5.1), and glutathione reductase (EC 1.6.4.2)], and the activities of nonenzyme antioxidant components, ascorbic acid and glutathione. Correlations between the proliferation of cancer cells and these antioxidant activities were calculated. At the species level, $F$. virginiana fruit extract inhibited the proliferation of A549 human lung epithelial cancer cells to a significantly greater extent $(34 \%$ inhibition) than the extracts from fruit of either $F$. chiloensis $(26 \%)$ or $F$. $\times$ ananassa $(25 \%)(P<0.0001)$. Extracts from fruit of $F$. virginiana also had significantly greater antioxidant activities and higher activities of antioxidant enzymes and nonenzyme components than did extracts from the other two species. Among individual genotypes, there was a high positive correlation between antiproliferation of A549 cancer cells, antioxidant activities against free radicals, activities of antioxidant enzymes, and activities of nonenzyme components. Although all fruit extracts from all the strawberry genotypes inhibited proliferation of A594 cancer cells, fruit extracts from seven $F$. virginiana genotypes showed significantly greater antiproliferative effects than any of the $F$. $\times$ ananassa or $F$. chiloensis genotypes. These genotypes, CFRA 0982, JP 95-1-1, NC 95-19-1, RH 30, NC 96-48-1, JP 95-9-6, and LH 50-4, may be especially useful in developing cultivars with greater anticancer potential.
\end{abstract}

Reactive oxygen species, including peroxyl radicals (ROO·), hydroxyl radicals $(\cdot \mathrm{OH})$, superoxide radicals $\left(\mathrm{O}_{2}^{-}\right)$, hydrogen peroxide $\left(\mathrm{H}_{2} \mathrm{O}_{2}\right)$, and singlet oxygen $\left({ }^{1} \mathrm{O}_{2}\right)$, are generated as byproducts of normal metabolism. The accumulation of these reactive oxygen species or free radicals can cause oxidative damage to lipids, proteins, and nucleic acids, and thus promote cell death (Morel and Dangl, 1997; SatuéGracia et al., 1997). Physiological defenses against oxidative stress involve small-molecule antioxidants and antioxidant proteins (Frei et al., 1992). Antioxidants are compounds that can delay or inhibit the oxidation of lipids or other molecules by inhibiting oxidizing chain reactions, and they play an important role as a health-protecting factor (Velioglu et al., 1998).

The antioxidant enzyme defense system consists of hundreds of different substances and mechanisms. Antioxidant enzymes have the capacity to lower the free radical burden and neutralize excess free radicals created by stress conditions. Antioxidant enzymes serve as catalysts that can affect one or

Received for publication 26 Dec. 2006. Accepted for publication 7 May 2007. Mention of trade names or commercial products in this publication is solely for the purpose of providing specific information and does not imply recommendation or endorsement by the U.S. Department of Agriculture or the National Institute for Occupational Safety and Health.

We thank Mr. Sam Garrett for propagating the plants for testing, Mr. John Enns for establishing and maintaining the strawberry field and harvesting fruit, Sue Kim for technical assistance, and Drs. Peter Trivonen, James J. Luby, John Hartung, and the anonymous reviewers for their helpful comments.

${ }^{1}$ Corresponding author. E-mail: wangs@ba.ars.usda.gov. more of the three stages of free radical formation: initiation, propagation, and termination. Therefore it is possible that antioxidant enzymes can prevent cellular and tissue damage in the human body (Baldwin, 1996; Bode and Dong, 2000).

Strawberries (Fragaria L.) are good sources of natural antioxidants (Heinonen et al., 1989; Wang et al., 2005). Previous studies showed that strawberry extracts exhibited high enzymatic activity for oxygen detoxification (Wang et al., 2005) and a high level of antioxidant capacity against free radical species including ROO., $\cdot \mathrm{OH}, \mathrm{O}_{2}^{--}, \mathrm{H}_{2} \mathrm{O}_{2}$, and ${ }^{1} \mathrm{O}_{2}$ (Wang and Jiao, 2000; Wang and Lin, 2000). The main antioxidant enzymes in strawberry fruit are superoxide dismutase (SOD), guaiacol peroxidase (G-POD), glutathione peroxidase (GSH-POD), ascorbate peroxidase (AsA-POD), monodehydroascorbate reductase (MDAR), dehydroascorbate reductase (DHAR), and glutathione reductase (GR), with ascorbic acid (AsA) and glutathione (GSH) as important nonenzyme components.

Strawberry extracts also exhibited chemopreventive and chemotherapeutic activities in vitro and in vivo (Carlton et al., 2001; Meyers et al., 2003; Wang et al., 2005), inhibited proliferation of the human lung epithelial cancer cell line A549, and decreased tetradecanoylphorbol-13-acetate (TPA)-induced neoplastic transformation of JB6 $\mathrm{P}^{+}$mouse epidermal cells (Wang et al., 2005). Pretreatment of JB6 $\mathrm{P}^{+}$mouse epidermal cells with strawberry extracts resulted in the inhibition of ultraviolet B (UVB)- and TPA-induced protein-1 (AP-1), and nuclear factor- $\mathrm{KB}(\mathrm{NF}-\kappa \mathrm{B})$ transactivation. Strawberry extracts 
also blocked TPA-induced phosphorylation of extracellular signal-regulated kinases (ERKs) and UVB-induced phosphorylation of ERKs and c-June amino terminal kinases (JNKs) in JB6 $\mathrm{P}^{+}$mouse epidermal cell culture (Wang et al., 2005).

AP-1 and NF- $\kappa$ B are transcription factors associated with carcinogenesis (Bode and Dong, 2000). AP-1 is composed of homodimers or heterodimers of the JUN and fructo-oligosaccharide (FOS) families (Angel and Karin, 1991). Many stimuli induce the binding of AP-1 to the promoter region of various genes that govern cellular processes such as inflammation, proliferation, and apoptosis (Baldwin, 1996). Inhibition of AP-1 activity has been shown to lead to suppression of cell transformation (Dong et al., 1997a). Some chemopreventive agents, including aspirin, tea polyphenols, and retinoic acid, have been reported to inhibit cell transformation and tumor promotion by suppressing AP-1 transactivation (Agadir et al., 1999; Dong et al., 1997a, b).

Nuclear factor- $\kappa \mathrm{B}$ is a heterodimeric protein composed of different combinations of members of the Rel family of transcription factors. The NF- $\kappa \mathrm{B}$-regulated genes are part of the larger Rel/NF- $\mathrm{BB}$ family of transcription factors involved mainly in stress-induced, immune, and inflammatory responses. Nuclear factor- $\kappa \mathrm{B}$ is also an important regulator in deciding cell fate, such as programmed cell death and proliferation control, and is critical in tumorigenesis (Baldwin, 1996). Reactive oxygen species (ROS) stimulate transcription by activating transcription factors such as AP-1 and NF- $\kappa$ B. Nuclear factor- $\kappa \mathrm{B}$ and AP-1 signal transduction pathways are important in transformation and tumor promotion (Bode and Dong, 2000). TPA or UVB are carcinogens and can produce ROS and stimulate AP-1 and NF- $\kappa$ B activity by activating mitogen-activated protein kinase (MAPK) signaling pathways such as the ERK1/2, JNKs, p38, and MEK1/2 MAP kinases (Hou et al., 2004; Schulze-Osthoff et al., 1997).

JB6 $\mathrm{P}^{+}$mouse epidermal cells are sensitive to tumor promoter treatment and provide a cell culture-based model for studying the mechanism of tumor promotion (Hsu et al., 2000). Transformation-sensitive JB6 $\mathrm{P}^{+}$cells are preferred for probing early events in oxidative stress-related signaling leading to carcinogenesis, and for identifying the molecular targets for chemoprevention (Dhar et al., 2002). Antioxidants and extracts of apple peel have been shown to inhibit AP-1 activity in JB6 cells (Ding et al., 2004; Dong et al., 1997a, b). Therefore, some component or components of strawberry extract may be highly effective as a chemopreventive agent that acts by targeting the downregulation of AP-1 and NF- $\kappa$ B activities, blocking MAPK signaling, and suppressing cancer cell proliferation and transformation.

Although generally considered high, the levels of antioxidants and antioxidant capacity in strawberry extracts from whole fruit vary considerably among genotypes (Wang and Lin, 2000). This may be true partly because the cultivated strawberry ( $F$. Xananassa) is a hybrid of two very different wild species (Darrow, 1966). The paternal progenitor species, $F$. virginiana, is distributed throughout North America and was originally collected from the East Coast. The maternal progenitor species, $F$. chiloensis, is distributed on a thin strip of the western American coastline extending from the Aleutians through South America. Accessions of the progenitor species are valued by strawberry breeders as sources of novel traits, especially pest resistance and abiotic stress tolerance. Because strawberry is a relatively new crop, dating to the 1700 s
(Darrow, 1966), as few as three backcrosses can yield selections of cultivar quality (J.F. Hancock, pers. comm.). Therefore, if thought to be of value in improving antioxidant capacity and health-promoting qualities, accessions from these progenitor species could be readily incorporated into a strawberry breeding program.

Neither of the progenitor species has been evaluated for anticancer capability or activities of antioxidant enzymes and nonenzyme components. A core subset of the Fragaria collection maintained at the U.S. Department of Agriculture National Clonal Repository, Corvallis, OR, has been constructed to contain a group of native $F$. virginiana and $F$. chiloensis thought to be of value to strawberry improvement. This core subset is being characterized for many horticultural traits useful to breeders (Hancock et al., 2001a, b), including resistance to black root rot, common foliar diseases, and nematodes (Hancock et al., 2001b, 2002; Pinkerton and Finn, 2005).

The objectives of this study are 1) to identify wild strawberry genotypes with high anticancer and antioxidant activities for use in cultivar development, 2) to evaluate the anticancer capability and activities of antioxidant enzymes and nonenzyme components in representatives of the two progenitor species ( $F$. virginiana and $F$. chiloensis) in comparison with representatives of the cultivated strawberry species $(F$. $\times$ ananassa), and 3 ) to determine which antioxidant activities are more closely correlated with anticancer activities among representatives of these three species.

\section{Materials and Methods}

Chemicals. Ascorbate, chlorogenic acid, $\beta$-carotene, histidine, $\mathrm{H}_{2} \mathrm{O}_{2}(30 \% \mathrm{w} / \mathrm{w})$, hydroxylamine hydrochloride, $N, N$ dimethyl- $p$-nitrosoaniline, xanthine, xanthine oxide, ascorbate oxidase, dithiothreitol (DTT), oxidized form of GSH (GSSG), GSH, GR, guaiacol, $\beta$-nicotinamide adenine dinucleotide $(\beta$ $\mathrm{NADH}$, reduced form), $\beta$-nicotinamide adenine dinucleotide phosphate $(\beta-\mathrm{NADPH}$, reduced form), nitro blue tetrazolium (NBT), resveratrol (3,5,4' -trihydroxystilbene), bovine serum albumin, Chelex 100, $\mathrm{FeSO}_{4}$, and MTT [3-(4, 5-dimethylthiazol-2-yl)-2, 5,-diphenyl tetrazolium bromide] solution were purchased from Sigma Chemical Co. (St. Louis). 6-Hydroxy-2, 5, 7, 8-tetramethylchroman-2-carboxylic acid (Trolox), and $\alpha$-tocopherol, and trichloroacetic acid were purchased from Aldrich (Milwaukee, WI). 2', 2' Azobis (2-amidinopropane) dihydrochloride was purchased from Wako Chemicals USA Inc. (Richmond, VA).

STRAWBERRY GENOTYPES. Eighteen genotypes of three strawberry species ( $F$. chiloensis, $F$. virginiana, and $F$. ×ananassa) (Table 1) were used in this study. Most of the accessions of wild strawberry, and one $F$. ×ananassa accession, were chosen because they are included in the core subset described by Hancock et al. (2002). Others were chosen based on past knowledge of their ability to thrive and produce fruit at Beltsville, MD. Three $F$. chiloensis accessions, $12 F$. virginiana accessions, and three $F$. ×ananassa accessions were selected. The F. ×ananassa cultivar, Allstar, was selected for its relatively low antioxidant capacity, whereas 'Ovation' was selected for its relatively high antioxidant capacity among cultivars from the U.S. Department of Agriculture, Agricultural Research Station strawberry breeding program at Beltsville, MD (Lewers et al., 2004). 
Table 1. Fragaria (strawberry) cultivars, selections, and wild genotypes grown on the north farm of the Henry A. Wallace Agricultural Research Center at Beltsville, MD, and evaluated for inhibition of A594 human lung cancer cell proliferation, activities against free radicals, activities of antioxidant enzymes, and nonenzyme components.

\begin{tabular}{|c|c|c|c|}
\hline Taxon & Plant introduction no. & Common name & Origin \\
\hline \multirow[t]{2}{*}{$\overline{F . \times a n a n a s s a}$} & PI 551406 & Allstar & Beltsville, MD \\
\hline & PI 634800 & Ovation & Beltsville, MD \\
\hline \multicolumn{4}{|l|}{ F. chiloensis ssp. } \\
\hline chiloensis f. patagonica & PI 612317 & 2 TAP 4B & La Tapera, Aisen, Chile \\
\hline F. chiloensis ssp. pacifica & PI 612488 & CFRA 1267 & British Columbia \\
\hline & PI 612495 & LH 50-4 & Montana \\
\hline & PI 612325 & NC 96-5-3 & Jones County, NC \\
\hline & PI 612323 & NC 96-35-2 & Greene County, AL \\
\hline & PI 612324 & NC 96-48-1 & Chester County, SC \\
\hline F. virginiana ssp. glauca & PI 552275 & CFRA 0982 & Near Ellsworth, ME \\
\hline & PI 612497 & Montreal River 10 & $\begin{array}{c}\text { Algoma District, } \\
\text { Ont., Canada }\end{array}$ \\
\hline & PI 612499 & RH 30 & Cook County, MN \\
\hline
\end{tabular}

EXPERIMENTAL DESIGN. The 18 strawberry genotypes were grown on the north farm of the Henry A. Wallace Agricultural Research Center at Beltsville, MD, using the advanced matted row production system (Black et al., 2002). Genotypes were randomly assigned to field plots in two blocks; each genotype was represented once in each block. In Summer 2005, plots were harvested individually. The fruit were hand harvested at a ripe stage; sorted to eliminate damaged, shriveled, and unripe fruit; and selected for uniform size and color. The fruit harvested from two plots of any genotype were kept separate for chemical analyses. From fruit of each plot, three subsamples were chemically analyzed separately, and means of the subsamples were combined to represent the fruit from each plot.

Fruit preparation. From fruit of each plot, undamaged berries were sorted randomly into three subsamples for separate analysis, frozen in liquid nitrogen, and then stored at $-80{ }^{\circ} \mathrm{C}$ until they were used for assays. The three subsamples were analyzed separately. After chemical analysis, the means of the subsamples were combined to represent the fruit from each plot.

\section{Free radical measurements}

ASSAY FOR PEROXYL RADICALS: OXYGEN RADICAL ABSORBANCE CAPACITY (ORAC). Triplicate strawberries $(5 \mathrm{~g})$ from each plot of each genotype were extracted with $20 \mathrm{~mL} 80 \%$ acetone (containing $0.2 \%$ formic acid) using a Polytron (Brinkmann Instruments, Inc., Westbury, NY). The homogenized samples from the acetone extraction were then centrifuged at $14,000 g_{n}$ for $20 \mathrm{~min}$ at $4{ }^{\circ} \mathrm{C}$. The supernatants were transferred to vials, stored at $-80^{\circ} \mathrm{C}$, and later used for ORAC analysis after suitable dilution.

The ORAC assay was carried out using a high-throughput instrument platform consisting of a robotic eight-channel liquid handling system (Precision 2000; Bio-Tek Instrument, Winooski, VT) and a microplate fluorescence reader (FL $\times 800$; Bio-Tek Instrument). Final ORAC values were calculated using the regression equation between Trolox concentra- tion and the net area under the curve, and were expressed as millimoles Trolox equivalents (TE) per kilogram fresh weight (FW) (Huang et al., 2002).

Assay fOr SUPEROXIDE RAdicals. Triplicate 100-g samples of strawberries from each plot of each genotype were pulverized and then centrifuged at $14,000 \mathrm{~g}_{\mathrm{n}}$ for $20 \mathrm{~min}$ at $4{ }^{\circ} \mathrm{C}$. The supernatants were transferred to vials stored at $-80{ }^{\circ} \mathrm{C}$ until used for analysis after suitable dilution. The antioxidant activity of the strawberry extract against $\mathrm{O}_{2} \cdot{ }^{-}$was determined using the methods of Richmond et al. (1981). The $\mathrm{O}_{2} \cdot{ }^{-}$was generated by the xanthine xanthine-oxidase system. The antioxidant activity against the $\mathrm{O}_{2} \cdot{ }^{-}$molecule was expressed as percentage inhibition of $\mathrm{O}_{2} \cdot{ }^{-}$production in the presence of fruit extract, and was expressed as millimoles TE per kilogram FW.

ASSAY FOR HYDROXYL RADICALS. Triplicate 100-g samples of strawberries from each plot of each genotype were pulverized and then centrifuged at $14,000 g_{n}$ for $20 \mathrm{~min}$ at $4{ }^{\circ} \mathrm{C}$. The supernatants were transferred to vials stored at $-80{ }^{\circ} \mathrm{C}$ until used for analysis after suitable dilution. The antioxidant activity of fruit extract against. $\mathrm{OH}$ was determined using the methods of Richmond et al. (1981). The $\cdot \mathrm{OH}$ in aqueous media was generated through the Fenton reaction. Relative scavenging efficiency (percentage inhibition of hydroxylation) of fruit extract was estimated from the difference in absorbance [optical density (OD)] with and without the addition of fruit extract. The antioxidant activity of fruit extract against the $\cdot \mathrm{OH}$ molecule was expressed as millimoles TE per kilogram FW.

Assay for singlet oxygen. Triplicate 100-g samples of strawberries from each plot of each genotype were pulverized and then centrifuged at $14,000 g_{n}$ for $20 \mathrm{~min}$ at $4{ }^{\circ} \mathrm{C}$. The supernatants were transferred to vials stored at $-80{ }^{\circ} \mathrm{C}$ until used for analysis after suitable dilution. The production of ${ }^{1} \mathrm{O}_{2}$ by sodium hypochlorite and $\mathrm{H}_{2} \mathrm{O}_{2}$ was determined according to Chakraborty and Tripathy (1992) with minor modifications, in which $N, N$, dimethyl- $p$ nitrosoaniline was used as a selective 
scavenger of ${ }^{1} \mathrm{O}_{2}$ and histidine was used as a selective acceptor of ${ }^{1} \mathrm{O}_{2}$. The bleaching of $N, N$, dimethyl- $p$ - nitrosoaniline was monitored spectrophotometrically at $440 \mathrm{~nm}$. Relative scavenging efficiency (percentage inhibition production of ${ }^{1} \mathrm{O}_{2}$ ) of fruit extract was estimated from the difference in absorbance of $N, N$, dimethyl- $p$ - nitrosoaniline with and without the addition of fruit extract. The antioxidant activity of fruit extract against the ${ }^{1} \mathrm{O}_{2}$ value was expressed as millimoles TE per kilogram FW.

\section{Antioxidant enzyme measurements}

Glutathione peroxidase, glutathione reductase, AND SUPEROXIDE DISMUTASE DETERMINATION. Triplicate fruit samples (10 g FW) from each plot of each genotype were homogenized in $10 \mathrm{~mL} 0.1 \mathrm{M}$ Tris-HCl buffer $(\mathrm{pH}, 7.8)$ containing $2 \mathrm{~mm}$ EDTA-Na and $2 \mathrm{~mm}$ DTT. The homogenate was centrifuged at $20,000 g_{\mathrm{n}}$ for $30 \mathrm{~min}$ at $4{ }^{\circ} \mathrm{C}$, and the supernatant was used for the GSH-POD and GR assays after suitable dilution. The supernatant was further purified according to Wang et al. (1991) before assaying the SOD enzyme activity.

Glutathione peroxidase activity was determined using the method of Tappel (1978), with a slight modification. The reaction mixture contained $0.1 \mathrm{M}$ Tris- $\mathrm{HCl}$ buffer $(\mathrm{pH}, 8.0)$, 0.4 mM EDTA, $1.0 \mathrm{~mm} \mathrm{NaN}_{3}, 1.0 \mathrm{~mm} \mathrm{H}_{2} \mathrm{O}_{2}, 1.0 \mathrm{~mm}$ GSH, 0.15 mM NADPH, $1 \mathrm{U}$ GR, and $100 \mu \mathrm{L}$ enzyme extract. The total reaction volume was $1.0 \mathrm{~mL}$. Hydrogen peroxide was added to start the reaction. Glutathione peroxidase activity was determined by the rate of NADPH oxidation at $340 \mathrm{~nm}$ via a spectrophotometer (Shimadzu UV-160A; Shimadzu Scientific Instruments, Columbia, MD). Enzyme activity was expressed as nanomoles NADPH oxidized per milligram protein per minute.

Glutathione reductase activity was assayed according to Smith et al. (1988). The activity of GR was determined by monitoring GSH-dependent oxidation of NADPH at $340 \mathrm{~nm}$. The oxidized form of glutathione was added to start the reaction, and the rate of oxidation was calculated using the extinction coefficient of NADPH $\left(6.22 \cdot \mathrm{mm}^{-1} \cdot \mathrm{cm}^{-1}\right)$. Glutathione reductase activity was expressed as nanomoles NADPH oxidized per milligram protein per minute.

Total SOD activity was assayed photochemically (Fridovich, 1986). Dicoumarol was included in the reaction mixture to inhibit reduction by pyridine nucleotide and to obtain a completely $\mathrm{O}_{2}^{-}$-dependent reduction of NBT. One unit of SOD was defined as the amount of enzyme that produced a $50 \%$ inhibition of NBT reduction under assay conditions. Because inhibition is not linearly correlated with SOD concentration, a $\mathrm{V} / \mathrm{V}$ transformation was used to obtain linearity, where $\mathrm{V}$ is the basic reaction rate without strawberry fruit extract and $\mathrm{v}$ is the reaction rate with extract. Linear correlation gave the equation

SOD units $\cdot \mathrm{ml}^{-1}=(0.459 \mathrm{~V} / \mathrm{v}-0.032) \times$ dilution factor

The correlation coefficient for this line was 0.985 .

ASCORBATE PEROXIDASE, GUAIACOL PEROXIDASE, MONODEHYDROASCORBATE REDUCTASE, AND DEHYDROASCORBATE REDUCTASE DETERMINATION. Triplicate fruit samples (10 g) from each plot of each genotype were pulverized in a cold mortar and pestle with $10 \mathrm{~mL}$ potassium phosphate buffer $(0.1 \mathrm{M} ; \mathrm{pH}, 7.3)$ containing $1 \mathrm{~mm}$ EDTA and $2 \mathrm{~mm}$ DTT. The homogenate was centrifuged at $12,000 g_{\mathrm{n}}$ for $10 \mathrm{~min}$ at $4{ }^{\circ} \mathrm{C}$. The supernatant was used for the AsA-POD, G-POD, MDAR, and DHAR assays after suitable dilution.

Ascorbate peroxidase activity was assayed according to the method of Amako et al. (1994). Hydrogen peroxide was added to start the reaction. Enzyme activity was expressed as nanomoles ascorbate oxidized per milligram protein per minute.

The G-POD assay mixture contained $0.1 \mathrm{M}$ phosphate buffer (pH, 6.1), $4 \mathrm{~mm}$ guaiacol as donor, $3 \mathrm{~mm} \mathrm{H}_{2} \mathrm{O}_{2}$ as substrate, and $1.0 \mathrm{~mL}$ crude enzyme extract. The total reaction volume was $3.0 \mathrm{~mL}$. The rate of change in absorbance at $420 \mathrm{~nm}$ was measured, and the level of enzyme activity was expressed as the difference in absorbance (OD) per milligram protein per minute.

The DHAR activity was assayed by measuring the rate of NADPH oxidation at $340 \mathrm{~nm}$. (Shigeoka et al., 1980). The reaction mixture contained $50 \mathrm{~mm}$ potassium phosphate, with a $\mathrm{pH}$ of $6.1,0.2 \mathrm{~mm}$ NADPH, $2.5 \mathrm{~mm}$ dehydroascorbate, $2.5 \mathrm{~mm}$ GSH, 0.6 U GR from Spinacia oleracea L., and $0.1 \mathrm{~mL}$ diluted fruit extract (twofold dilution). The reaction was started by adding dehydroascorbate. Enzyme activity was expressed as nanomoles NADPH oxidized per milligram of protein per minute.

The MDAR activity was assayed by measuring the rate of NADH oxidation at $340 \mathrm{~nm}$ (Nakagawara and Sagisaka, 1984). The reaction mixture contained $50 \mathrm{~mm}$ potassium phosphate buffer (pH, 7.3), 0.2 mM NADH, $1.0 \mathrm{~mm}$ ascorbate, $1.0 \mathrm{U}$ ascorbate oxidase, and $0.1 \mathrm{~mL}$ diluted fruit juice (twofold dilution) in a total volume of $1.0 \mathrm{~mL}$. The reaction was started by adding ascorbate oxidase from Cucurbita L. (EC 1.10.3.3). Enzyme activity was expressed as nanomoles NADH oxidized per milligram protein per minute.

Ascorbic ACID AND GLUTATHIONE DETERMinAtion. For measurement of AsA, triplicate fruit samples of $4 \mathrm{~g}$ from each plot of each genotype were pulverized and homogenized with a cold mortar and pestle using $8 \mathrm{~mL}$ ice-cooled 5\% trichloroacetic acid. The homogenate was filtered through four layers of miracloth and centrifuged at $16,000 g_{\mathrm{n}}$ for $10 \mathrm{~min}$ at $4{ }^{\circ} \mathrm{C}$. The supernatant was used for the AsA assays. Ascorbic acid level was determined using the methods of Arakawa et al. (1981). A standard curve in the range 0 to $10 \mu \mathrm{mol}$ AsA was used.

For measurement of GSH, triplicate strawberry fruit samples of $4 \mathrm{~g}$ were homogenized in $8.0 \mathrm{~mL}$ ice-cold, degassed $7.57 \mathrm{~mm}$ sodium ascorbate solution with chilled mortar and pestle under $\mathrm{N}_{2}$ at $0{ }^{\circ} \mathrm{C}$. The homogenate was filtered through four layers of miracloth and centrifuged at $30,000 g_{n}$ for $15 \mathrm{~min}$ at $0{ }^{\circ} \mathrm{C}$. The supernatant was deproteinized in glass test tubes by incubation in a water bath at $100{ }^{\circ} \mathrm{C}$ for $3 \mathrm{~min}$ and then centrifuged at $15,000 g_{\mathrm{n}}$ for $15 \mathrm{~min}$ at $0{ }^{\circ} \mathrm{C}$. The supernatants were used for the GSH assay. Glutathione was assayed using the method described by Castillo and Greppin (1988).

MTT ASSAY FOR INHIBITION OF PROLIFERATION OF CANCER CELLS. MTT assay is a standard colorimetric assay for measuring cellular proliferation (cell growth). The amount of yellow MTT reduced to purple formazan is measured spectrophotometrically. This reduction takes place only when mitochondrial reductase enzymes are active, and thus conversion is directly related to the number of viable cells. For the assay to determine the level of inhibition of proliferation of the human lung epithelial cancer A549 cells (MTT assay), strawberry extracts were prepared by mixing $50 \mathrm{~g}$ strawberries with $50 \mathrm{~mL}$ distilled $\mathrm{H}_{2} \mathrm{O}$ blended at high speed. The blended homogenates were strained, centrifuged at $6000 \mathrm{~g}_{\mathrm{n}}$ at $4{ }^{\circ} \mathrm{C}$ for $20 \mathrm{~min}$, and the supernatants were filtered. The supernatants were transferred to vials and stored at $-80^{\circ} \mathrm{C}$ until used for analysis after suitable dilution. 
Human lung cancer cells, cell line A549, were grown in Dulbecco's minimal essential medium supplemented with $10 \%$ fetal bovine serum, $50 \mathrm{U} \cdot \mathrm{mL}^{-1}$ penicillin, and $50 \mu \mathrm{g} \cdot \mathrm{mL}^{-1}$ streptomycin in $75 \mathrm{~cm}^{2} \mathrm{~T}$ flasks at $37{ }^{\circ} \mathrm{C}, 85 \%$ humidity, and $5 \% \mathrm{CO}_{2}$ atmosphere. Subcultures were carried out every 2 to $3 \mathrm{~d}$ using a $0.25 \%$ trypsin and $0.02 \%$ EDTA solution. Briefly, A549 cells were plated in their growth medium at a density of $10^{4}$ cells per well in 96-well flat-bottomed well cell culture plates and incubated at $37^{\circ} \mathrm{C}$. Twenty-four hours after plating, $0.33 \mu \mathrm{L}$ strawberry extract (equal to $2.5 \mu \mathrm{g} \mathrm{FW}$ ) was added to each well (except for control wells). After a 48-h incubation, $10 \mu \mathrm{L}$ MTT solution was added in each well to form formazan salt crystals, and the plates were further incubated for $4 \mathrm{~h}$. Then $100 \mu \mathrm{L}$ solubilization solution [10\% sodium dodecyl sulfate (SDS) in $0.01 \mathrm{M} \mathrm{HCl}$ ] was added and the plate was incubated overnight at $37{ }^{\circ} \mathrm{C}$. The amount of formazan produced was proportional to the number of viable cells (Mosmann, 1983). After incubation, the MTT-formazan was solubilized in 2propanol and the OD was measured at a wavelength of $575 \mathrm{~nm}$, with a reference wavelength of $690 \mathrm{~nm}$, using a microplate spectrophotometer (Spectra MAX 250; Molecular Devices, Inc. Sunnyvale, CA), where higher OD values indicated more cell proliferation. Proliferation was expressed as a percentage of cell growth in wells that received no extract. Inhibition of proliferation was expressed as $100 \%$ minus the proliferation percentage.

Protein Determination. The amount of total protein present in the fruit extract was estimated, according to Bradford (1976), for each of the enzyme assays. Bovine serum albumin, in a range from 0 to $30 \mu \mathrm{g}$, was used as a comparative standard. When the total amount of protein present in the fruit extract was determined, this amount was used to calculate the activity levels for each of the antioxidant enzymes.

Statistical analysis. To determine whether different strawberry genotypes had different inhibitory effects on cancer cell proliferation or different antioxidant activities, an analysis of variance (ANOVA) was done using SAS version 9.1.3 (SAS Institute, Cary, NC). The data were analyzed using the proc mixed command. The model in these analyses was that the observed variation for inhibition of cancer cell proliferation (MTT assay); antioxidant activities against ROO-, $\mathrm{O}_{2}^{--}, \cdot \mathrm{OH}$, and ${ }^{1} \mathrm{O}_{2}$ radicals; and antioxidant enzyme activities was a result of the genotype, and that the effects of the two blocks was random. Differences at $P<0.05$ were considered significant.

To determine whether there may be general differences at the strawberry species level for inhibitory effects on cancer cell proliferation, or antioxidant activities, a second ANOVA used the model that observed variation was the result of species differences. Differences at $P<0.05$ were considered significant.

A third ANOVA was done that was identical to the second, except data from only three $F$. virginiana genotypes were included to confirm the analysis was not biased as a result of having many more representatives of $F$. virginiana compared with only three representatives of either $F$. chiloensis or $F$. ×ananassa. The three genotypes selected were those with the lowest MTT assay means according to the first analysis: Montreal River 10, NC 96-35-2, and Frederick 9.

To determine which antioxidant activities against free radicals, antioxidant enzymes, and nonenzyme (AsA, GSH) components are more closely correlated with anticancer activity (cell viability, MTT uptake) among representatives of these three strawberry species, correlation coefficients were calcu- lated using Excel 2003 (Microsoft Corp., Redmond, WA) and are reported as $R^{2}$ values.

\section{RESULTS}

Antioxidant aCtivity. The scavenging capacities against $\mathrm{ROO} \cdot, \cdot \mathrm{OH}, \mathrm{O}_{2}^{--}$, and ${ }^{1} \mathrm{O}_{2}$ in various strawberry cultivars, selections, and wild genotypes are shown in Fig. 1. The scavenging capacity values against ROO ranged from 27.98 to $61.69 \mathrm{TE}$ per $\mathrm{mmol} \cdot \mathrm{kg}^{-1} \mathrm{FW}$. The $F$. virginiana ssp. glauca (S. Watson) Staudt accession from Maine, CFRA 0982 had the highest ROO. scavenging activity, followed by JP 95-1-1 [F. virginiana ssp. grayana (Vilm. ex J. Gay) Staudt], RH 30 ( $F$. virginiana ssp. virginiana), NC 96-48-1 ( $F$. virginiana), NC 9635-2 ( $F$. virginiana), JP 95-9-6 ( $F$. virginiana), Montreal River 10 ( $F$. virginiana ssp. virginiana), NC 95-19-1 ( $F$. virginiana ssp. grayana), Frederick 9 ( $F$. virginiana ssp. virginiana), LH 50-4 (F. virginiana), 2 TAP 4B [F. chiloensis ssp. chiloensis $\mathrm{f}$. patagonica Staudt], NC 95-21-1 ( $F$. virginiana ssp. grayana), CFRA 0368 (F. chiloensis), and CFRA 1267 (F. chiloensis ssp. pacifica Staudt). 'Allstar', CFRA 0638, and 'Ovation', the three $F$. ×ananassa genotypes, had the lowest scavenging capacities on ROO radicals.

The scavenging capacity for $\cdot \mathrm{OH}$ ranged from 12.98 to 23.12 TE per mmol. $\mathrm{kg}^{-1} \mathrm{FW}$, reflecting a 1.78 -fold difference among genotypes (Fig. 1). CFRA 0982 had the highest scavenging capacity for the $\cdot \mathrm{OH}$ free radical $\left(23.12 \mathrm{TE}\right.$ per $\left.\mathrm{mmol} \cdot \mathrm{kg}^{-1} \mathrm{FW}\right)$. This equates to a $60.16 \%$ inhibition of $\cdot \mathrm{OH}$ activity. The percent inhibition of $\cdot \mathrm{OH}$ activity was determined by comparing berry fruit extract against "blanks," which had been prepared similarly but without berry fruit extract. Meanwhile, 'Allstar' had the lowest $\cdot \mathrm{OH}$ scavenging efficiency with only $33.78 \%$ inhibition of $\cdot \mathrm{OH}$ activity. The scavenging capacity of these strawberry genotypes ranged from 7.01 to16.95 TE per $\mathrm{mmol} \cdot \mathrm{kg}^{-1} \mathrm{FW}$ against ${ }^{1} \mathrm{O}_{2}$, and ranged from 3.32 to 11.79 TE per mmol. $\mathrm{kg}^{-1} \mathrm{FW}$ against $\mathrm{O}_{2}^{--}$(Fig. 1). The relative scavenging efficiency (percentage inhibition of radical production) on ${ }^{1} \mathrm{O}_{2}$ and $\mathrm{O}_{2}^{--}$ranged from $18.87 \%$ to $45.63 \%$ and $27.45 \%$ to $81.54 \%$ respectively. CFRA 0982 had the best scavenging capacity for the reactive oxygen species not only for ROO. and $\cdot \mathrm{OH}$, but also for ${ }^{1} \mathrm{O}_{2}$, and $\mathrm{O}_{2}^{--}$, with 16.95 and $11.79 \mathrm{TE}$ per mmol. $\mathrm{kg}^{-1} \mathrm{FW}$ respectively for ${ }^{1} \mathrm{O}_{2}$, and $\mathrm{O}_{2}^{-}$ (Fig. 1), which equates to relative scavenging efficiencies of $45.63 \%$ for ${ }^{1} \mathrm{O}_{2}$ and $81.54 \%$ for $\mathrm{O}_{2}^{--}$. Meanwhile, 'Allstar' had the lowest ability to inhibit free radical activity for ${ }^{1} \mathrm{O}_{2}$, and $\mathrm{O}_{2}^{--}$with 7.01 and $3.32 \mathrm{TE}$ per $\mathrm{mmol} \cdot \mathrm{kg}^{-1} \mathrm{FW}$ respectively.

At the species level, extracts from fruit of $F$. virginiana had the highest scavenging oxygen species capacities compared with $F$. chiloensis and $F$. Xananassa (Table 2 ). When the comparison was limited to the $F$. virginiana representatives lowest in inhibition of cancer cell proliferation (NC96-35-2, Frederick 9, and Montreal River 10) to balance the number of accessions representing each species, the scavenging capacity of $F$. virginiana extracts for all the free radicals tested was significantly greater than that of $F$. chiloensis, which was significantly greater than that of $F$. ×ananassa (Table 2).

Antioxidant ENZYMes AND nONENZYMe Components. Different activities of antioxidant enzymes and content of nonenzyme components were detected in different strawberry genotypes (Figs. 2-4). CFRA 0982 had the highest activity of the peroxidase AsA-POD. CFRA 0982 and the $F$. virginiana ssp. grayana accession from Mississippi, NC 95-19-1 had the 



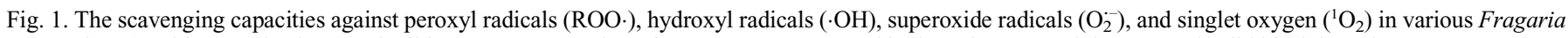
(strawberry) cultivars, selections, and wild genotypes. Gray bars denote $F$. ×ananassa, white bars denote $F$. chiloensis, and solid black bars denote $F$. virginiana Data expressed as Trolox equivalents (TE) millimoles per kilogram fresh weight. Differences between genotypes were determined with an analysis of variance using SAS version 9.1.3 (SAS Institute, Cary, NC). The data were analyzed using the proc mixed command. Different letters indicate significant differences at $P \leq 0.05$.

highest levels of activity for the peroxidases G-POD and GSH-POD. In addition, NC 95-19-1 had the highest level of SOD followed by CFRA 0982 . CFRA 0982 and the F. virginiana accession from Florida, JP 95-1-1, had the highest level of activity for the reductase GR. These two accessions plus the $F$. virginiana accession from North Carolina, NC96-5-3, had the highest level of activity for DHAR. JP 95-1-1 had the highest level of activity for MDAR, followed by CFRA 0982. CFRA 0982 and NC 95-19-1 had the highest levels of the nonenzyme component AsA, whereas CFRA 0982 and the $F$. virginiana accession from South Carolina, NC 96-48-1, had the highest levels of the nonenzyme component GSH. Meanwhile one or more of the $F$. xananassa genotypes had the lowest activities of all antioxidant enzymes and nonenzyme components, AsA and GSH (Figs. 2-4).

Among all species used in this study, extracts from fruit of $F$. virginiana had the highest activities of antioxidant enzymes (SOD, G-POD, GSH-POD, AsA-POD, MDAR, DHAR, and GR) and nonenzyme components (AsA and GSH) compared with $F$. chiloensis and $F$. Xananassa. However, when only the three representatives of $F$. virginiana (NC 96-35-2, Frederick 9, and Montreal River 10, the $F$. virginiana accessions with the lowest percentage inhibition of A549 human lung epithelial cancer cells) were used in the comparison, the G-POD and DHAR activity levels of $F$. virginiana fruit extract were not significantly different from those of $F$. chiloensis (Table 2). When all representatives of the three species were compared, antioxidant enzyme and non- enzyme component activities were not significantly different between fruit extracts of $F$. chiloensis and $F$. xananassa. However, when only the three representatives of $F$. virginiana that were lowest in inhibition of cancer cell proliferation (NC 96-35-2, Frederick 9, and Montreal River 10) were used in the comparison, fruit extracts of $F$. Xananassa were significantly lower in SOD, GSH-POD, MDAR, and GR activities.

INHIBITION OF PROLIFERATION OF CANCER CELLS. Antiproliferative activities of different genotypes of strawberry fruit extracts on the growth of human lung epithelial cancer A549 cells in vitro are summarized in Fig. 5. All genotypes of strawberry extracts showed inhibition of cancer cells proliferation. CFRA 0982 and JP 95-1-1 exhibited the greatest level of inhibition of A594 cancer cells, followed by NC 95-19-1, the $F$. virginiana ssp. virginiana $\mathrm{RH} 30$, and NC 96-48-1. Fruit extracts from seven $F$. virginiana genotypes showed significantly greater antiproliferative effects than any of the $F$. Xananassa or $F$. chiloensis genotypes. These genotypes are CFRA 0982, JP 95-1-1, NC 95-19-1, RH 30, NC 96-48-1, JP 95-9-6, and LH 50-4. The antiproliferative activities of strawberry fruit were expressed as MTT uptake, which was measured at a wavelength at $575 \mathrm{~nm}$, where lower OD values indicate fewer cells and higher antiproliferative activities (Fig. 5).

At the species level, $F$. virginiana fruit extract inhibited the proliferation of A549 human lung epithelial cancer cells to a significantly higher extent $(34 \%$ less than the uninhibited reference test) than the extracts from fruit of either $F$. chiloensis 
Table 2. The inhibition of A549 human lung epithelial cancer cells (compared with 0.00 or $0 \%$ inhibition using a control with no extract added), scavenging capacities of reactive oxygen species, the activities of antioxidant enzymes and nonenzyme antioxidants in fruit extracts from representatives of three species of strawberries (Fragaria virginiana, F. chiloensis, and F. ×ananassa).

\begin{tabular}{|c|c|c|c|c|}
\hline & Fragaria virginiana $^{z}$ & F. chiloensis ${ }^{\mathrm{y}}$ & F. $\times$ ananassa $^{\mathrm{x}}$ & $\mathrm{F}$ values $^{\mathrm{w}}$ \\
\hline Inhibition of A549 human lung epithelial cancer cells & $0.34 \mathrm{a}(0.30 \mathrm{a})$ & $0.26 \mathrm{~b}$ & $0.25 \mathrm{~b}$ & $46.37 * *$ \\
\hline \multicolumn{5}{|l|}{ Scavenging capacities of oxygen species } \\
\hline Peroxyl radicals $\left[\mathrm{TE}\left(\mathrm{mmol} \cdot \mathrm{kg}^{-1} \mathrm{FW}\right)\right]$ & $47.11 \mathrm{a}(45.32 \mathrm{a})$ & $39.26 \mathrm{~b}$ & $32.60 \mathrm{c}$ & $17.86^{* *}$ \\
\hline Superoxide radicals $\left[\mathrm{TE}\left(\mathrm{mmol} \cdot \mathrm{kg}^{-1} \mathrm{FW}\right)\right]$ & $8.02 \mathrm{a}(6.51 \mathrm{a})$ & $5.06 \mathrm{~b}$ & $3.88 \mathrm{~b}(\mathrm{c})$ & $19.22 * *$ \\
\hline Singlet oxygen $\left[\mathrm{TE}\left(\mathrm{mmol} \cdot \mathrm{kg}^{-1} \mathrm{FW}\right)\right]$ & $12.92 \mathrm{a}(11.41 \mathrm{a})$ & $9.04 \mathrm{~b}$ & $7.28 \mathrm{~b}(\mathrm{c})$ & $31.83 * *$ \\
\hline \multicolumn{5}{|l|}{ Antioxidant enzymes } \\
\hline Glutathione peroxidase $\left(\mathrm{nmol} \cdot \mathrm{mg}^{-1}\right.$ protein $\left./ \mathrm{min}\right)$ & $76.80 \mathrm{a}(59.65 \mathrm{a})$ & $45.37 \mathrm{~b}$ & $38.09 \mathrm{~b}(\mathrm{c})$ & $18.37 * *$ \\
\hline Ascorbate peroxidase $\left(\mathrm{nmol} \cdot \mathrm{mg}^{-1}\right.$ protein $\left./ \mathrm{min}\right)$ & $34.62 \mathrm{a}(28.68 \mathrm{a})$ & $17.00 \mathrm{~b}$ & $17.41 \mathrm{~b}$ & $27.44 * *$ \\
\hline Monodehydroascorbate reductase $\left(\mathrm{nmol} \cdot \mathrm{mg}^{-1} \operatorname{protein} / \mathrm{min}\right)$ & 38.39 a $(30.45 \mathrm{a})$ & $26.04 \mathrm{~b}$ & $20.68 \mathrm{~b}(\mathrm{c})$ & $12.49 * *$ \\
\hline Dehydroascorbate reductase $\left(\mathrm{nmol} \cdot \mathrm{mg}^{-1}\right.$ protein $\left./ \mathrm{min}\right)$ & 8.18 a $(7.07 \mathrm{a})$ & $5.95 \mathrm{~b}(\mathrm{ab})$ & $5.00 \mathrm{~b}$ & $10.50 * *$ \\
\hline Glutathione reductase $\left(\mathrm{nmol} \cdot \mathrm{mg}^{-1}\right.$ protein $\left./ \mathrm{min}\right)$ & 17.49 a $(16.46$ a) & $11.20 \mathrm{~b}$ & $9.16 \mathrm{~b}(\mathrm{c})$ & $29.33 * *$ \\
\hline
\end{tabular}

${ }^{\mathrm{Z}}$ Different letters in the same row indicate statistical significant differences at $P \leq 0.01$. Letters in parentheses indicate that the significance of the differences between species means changed when the analyses included only the three $F$. virginiana accessions with the lowest percentage inhibition of A549 human lung epithelial cancer cells: NC 96-35-2, Frederick 9, and Montreal River 10.

${ }^{y}$ Each value in this column (not in parentheses) is the mean value of $F$. virginiana representatives JP 95-1-1, JP 95-9-6, LH 50-4, NC 96-5-3, NC 96-35-2, NC 96-48-1, CFRA 0982, NC 95-19-1, NC 95-21-1, Frederick 9, Montreal River 10, and RH 30. Values in parentheses are means of NC 96-35-2, Frederick 9, and Montreal River 10, the F. virginiana accessions with the lowest percentage inhibition of A549 human lung epithelial cancer cells.

${ }^{\mathrm{x}}$ Each value in this column is the mean value of CFRA 0368, 2 TAP 4B, and CFRA 1267.

"Each value in this column is mean value of 'Allstar', CFRA 0638, and 'Ovation'.

Differences between genotypes were determined with an analysis of variance using SAS version 9.1.3 (SAS Institute, Cary, NC). The data were analyzed using the proc mixed command.

$* * P<0.0001$.

$\Delta \mathrm{A}$, difference in absorbance between two readings; TE, Trolox equivalent.

$(26 \%)$ or $F$. $\times$ ananassa $(25 \% ; P<0.0001)$. When only the three $F$. virginiana representatives with the least inhibitory effect were compared with the three representatives from the other two species, the $F$. virginiana fruit extracts still had a significantly greater inhibitory effect $(30 \%)$. The difference in inhibitory effect between $F$. chiloensis and $F$. ×ananassa was not significant.

Correlations. In this study, positive correlations were observed between inhibition of A594 lung epithelial cancer cell proliferation (MTT assay) and all antioxidant-related chemical components tested, including activities against four free radicals, activities of seven antioxidant enzymes, and two nonenzyme components. The highest correlations between inhibition of A549 cancer cell proliferation and any of the antioxidant measures we tested were with the antioxidant enzyme AsA-POD $\left(R^{2}=0.947\right)$, the activity against the free radical $\cdot \mathrm{OH}\left(R^{2}=0.915\right)$, and the antioxidant enzyme GR $\left(R^{2}=\right.$ 0.904). Among both species and individual genotypes, there was a high positive correlation between inhibition of A549 cancer cell proliferation and antioxidant activities against free radicals, with $R^{2}$ values of $0.868,0.884,0.915$, and 0.884 for $\mathrm{ROO} \cdot \mathrm{O}_{2}^{--}, \cdot \mathrm{OH}$, and ${ }^{1} \mathrm{O}_{2}$ respectively (Table 3 ). A positive correlation also was found between cancer cell proliferation activity and activities of antioxidant enzymes, and nonenzyme components. The correlation values $\left(R^{2}\right)$ between inhibition of cancer cell proliferation and SOD, G-POD, GSH-POD, ASHPOD, MDAR, DHAR, and GR were 0.745, 0.740, 0.875, 0.947,
$0.882,0.867$, and 0.904 respectively (Table 3 ). The positive correlation values between inhibition of cancer cell proliferation and nonenzyme components were 0.708 and 0.755 for AsA and GSH respectively (Table 3 ).

\section{Discussion}

The results of this study showed that fruit of several wild strawberry accessions contain high antioxidants and have high antioxidant activities against $\mathrm{ROO} \cdot, \cdot \mathrm{OH}, \mathrm{O}_{2}^{--}$, and ${ }^{1} \mathrm{O}_{2}$. Different genotypes showed varying degrees of scavenging capacity on various radicals and among all the genotypes tested. CFRA 0982 had the highest scavenging capacity of active oxygen species. Free radicals are inherently unstable, because they are highly reactive and contain "extra" energy. To reduce their energy load, free radicals react with certain chemicals in the body, and in the process interfere with the cells' ability to function normally (Halliwell and Gutteridge, 1989). Antioxidants work in several ways to suppress free radicals: They may reduce the energy of the free radical, stop the free radical from forming in the first place, or interrupt an oxidizing chain reaction to minimize the damage incited by free radicals (Frei et al., 1992).

Natural antioxidant enzymes manufactured in the body provide an important defense against free radicals. Antioxidant enzymes exhibit synergistic interactions by protecting each other from specific free radical attacks (Blum and Fridovich, 



Fig. 2. Activities of antioxidant enzymes [superoxide dismutase (SOD), guaiacol peroxidase (G-POD), glutathione peroxidase (GSH-POD), and ascorbate peroxidase (AsA-POD)] in various Fragaria (strawberry) cultivars, selections, and wild genotypes. Gray bars denote $F$. $\times a$ ananassa, white bars denote $F$. chiloensis, and solid black bars denote $F$. virginiana. Differences between genotypes were determined with an analysis of variance using SAS version 9.1.3 (SAS Institute, Cary, NC). The data were analyzed using the proc mixed command. Different letters indicate significant differences at $P \leq 0.05$. $\Delta \mathrm{A}$, difference in absorbance between two readings.

1985), and they have the capacity to lower the free radical burden and neutralize excess free radicals created by stress conditions. Antioxidant enzymes serve as catalysts that can act at one or more of the three stages of free radical formation: initiation, propagation, and termination (Hong and Sporn, 1997). Therefore it is possible that antioxidant enzymes can prevent cellular and tissue damage in the human body. Glutathione peroxidase, GR, catalase, and SOD are among the most important antioxidant enzymes. The production of antioxidant enzymes in strawberry fruit is a complex process that is not yet totally understood. The antioxidant enzyme defense system consists of hundreds of different substances and mechanisms. The main antioxidant enzymes in strawberry fruit are SOD, G-POD, GSH-POD, AsA-POD, MDAR, DHAR, and GR. Different activities of antioxidant enzymes and content of nonenzyme components were detected in different strawberry genotypes (Figs. 2-4).

Superoxide dismutase activities in strawberry genotypes in this study range from 5.10 to $23.42 \mathrm{U} \cdot \mathrm{mg}^{-1}$ protein. Superoxide dismutase is a primary antioxidant enzyme and catalyzes the breakdown of $\mathrm{O}_{2}^{--}$to $\mathrm{O}_{2}$ and $\mathrm{H}_{2} \mathrm{O}_{2}$, removes ${ }^{1} \mathrm{O}_{2}$ as well as $\mathrm{O}_{2}^{--}$, prevents formation of $\cdot \mathrm{OH}$ (Fridovich, 1986), and has been implicated as an essential defense against the potential toxicity of oxygen (McCord, 1979).

The activity of GSH-POD is correlated to antioxidant activity (Table 3). Guaiacol peroxidase is involved in a large number of biochemical and physiological processes and is abundant in cytosolic and mitochondrial compartments. The biological function of G-POD is to remove $\mathrm{H}_{2} \mathrm{O}_{2}$ and other hydroperoxides for protection against lipid peroxidation and DNA hydroperoxides (Chaudiere and Ferrari-Iliou, 1999). The mode of action of G-POD on the $\mathrm{H}_{2} \mathrm{O}_{2}$ substrate is to liberate free radicals that may be scavenged by catalase and GSH-POD.

Ascorbate peroxidase activity positively correlates with AsA and the scavenging capacity for ROO., $\cdot \mathrm{OH},{ }^{1} \mathrm{O}_{2}$, and $\mathrm{O}_{2}^{--}$content in strawberry fruit extracts (Table 3 ). Ascorbate peroxidase is a heme-containing protein and is highly specific for ascorbate as the electron donor. The basic properties of AsA-POD are very different from those of G-POD with regard to its amino sequences and other molecular properties (Asada, 1992). Ascorbic acid serves as an excellent antioxidant and plays a fundamental role in the removal of $\mathrm{H}_{2} \mathrm{O}_{2}$ via the ascorbate- $\mathrm{GSH}$ cycle and produces dehydroxyascorbic acid. Dehydroxyascorbic acid is reduced to ascorbic acid by MDAR or DHAR at the expense of NADH and GSH (Halliwell and Gutteridge, 1989).

The correlation coefficient $\left(R^{2}\right)$ for GR activities and scavenging capacities on oxygen species were also evident (Table 3). Genotypes with high activity of GR and other antioxidants enzymes were also found to have high antioxidant activity. Glutathione reductase is a ubiquitous NADPH-dependent enzyme and is present in cells of both plants and animals. The enzyme GSH-POD uses reduced GSH to eliminate $\mathrm{H}_{2} \mathrm{O}_{2}$ : $2 \mathrm{GSH}+\mathrm{H}_{2} \mathrm{O}_{2} \rightarrow \mathrm{GSSG}+2 \mathrm{H}_{2} \mathrm{O}$. Glutathione reductase then adds hydrogen ions to GSSG to regenerate GSH. A high GSHto-GSSG ratio indicates a high level of GSH available for antioxidant activity. It has been suggested that in higher plants, GR may be a rate-limiting enzyme for defense against active $\mathrm{O}_{2}$ toxicity (Gossett et al., 1996; Tanaka, 1994). 



Fig. 3. Activities of antioxidant enzymes [monodehydroascorbate reductase (MDAR), dehydroascorbate reductase (DHAR), and glutathione reductase (GR)] in various Fragaria (strawberry) cultivars, selections, and wild genotypes. Gray bars denote $F$. ×ananassa, white bars denote $F$. chiloensis, and solid black bars denote $F$. virginiana. Differences between genotypes were determined with an analysis of variance using SAS version 9.1.3 (SAS Institute, Cary, NC). The data were analyzed using the proc mixed command. Different letters indicate statistical significant differences at $P \leq 0.05$.

Antioxidants are notable for boosting the immune system because immune system cells in the bloodstream are so easily accessed by free radicals as well as by antioxidants. Antioxidants are molecules that can neutralize free radicals by accepting or donating an electron to eliminate the unpaired condition. Typically this means that the antioxidant molecule becomes a free radical in the process of neutralizing a free radical molecule to a nonfree radical molecule. Ascorbate can donate a hydrogen atom to a free radical molecule, thereby neutralizing the free radical while becoming an ascorbate radical itself. But the ascorbate radical is very stable because of its resonance structure. Moreover, ascorbate is readily regenerated from the ascorbate radical with NADH or NADPH-dependent reductases (Hossain and Asada, 1997). The correlations between scavenging capacities on ROO. (ORAC values) and AsA content, $\cdot \mathrm{OH}$, $\mathrm{O}_{2}^{--}$, and ${ }^{1} \mathrm{O}_{2}$ were also evident.
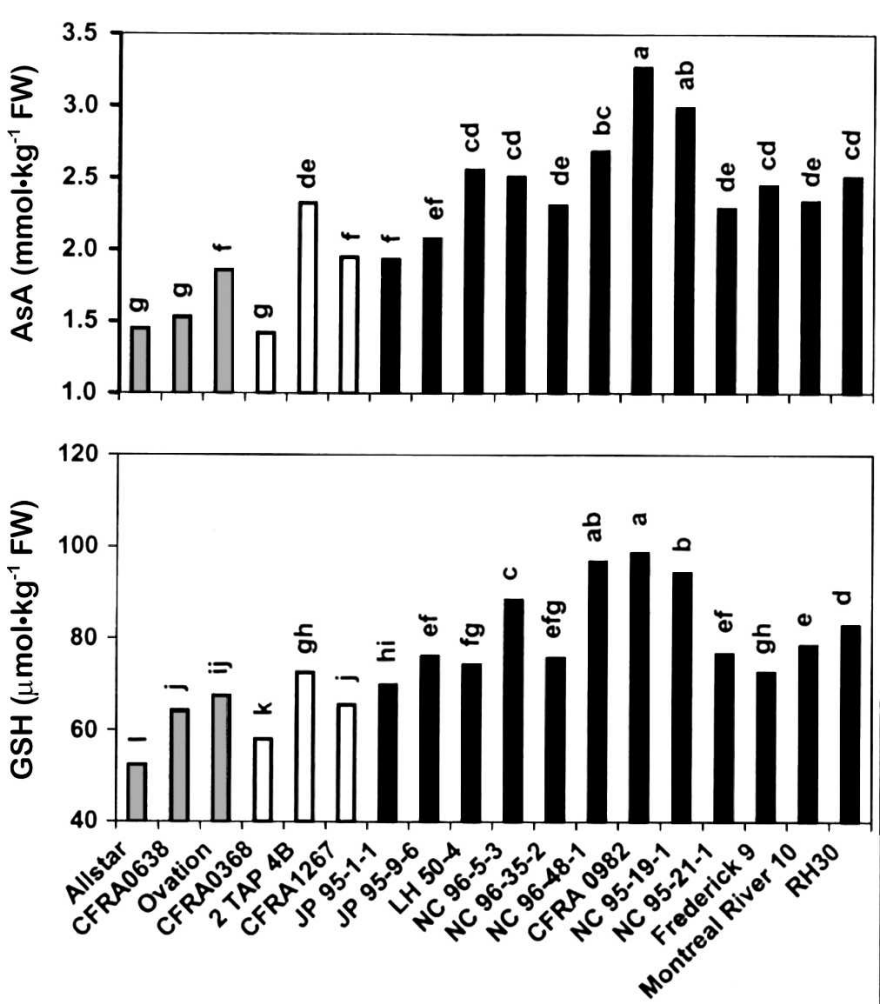

Fig. 4. The content of nonenzyme antioxidants [ascorbic acid (AsA) and reduced glutathione (GSH)] in various Fragaria (strawberry) cultivars, selections, and wild genotypes. Gray bars denote $F$. ×ananassa, white bars denote $F$. chiloensis, and solid black bars denote $F$. virginiana. Differences between genotypes were determined with an analysis of variance using SAS version 9.1.3 (SAS Institute, Cary, NC). The data were analyzed using the proc mixed command. Different letters indicate statistical significant differences at $P \leq 0.05$.

Glutathione is another important antioxidant. It readily interacts with free radicals, especially hydroxyl and carbon radicals, by donating a hydrogen atom. Reactions of this type provide protection by neutralizing reactive hydroxyl radicals. Glutathione plays an important role in the stabilization of many enzymes. It also serves as a substrate for DHAR and reacts directly with free radicals, including the hydroxyl radical, to prevent the inactivation of enzymes by oxidation of the essential thiol group. The majority of GSH in the cell is maintained in the reduced state (Kosower and Kosower, 1978). A high level of GSH is necessary for several physiological functions. This includes activation and inactivation of redox-dependent enzyme systems (Ziegler, 1985).

Antiproliferative activities of strawberry fruit extracts on the growth of human lung epithelial cancer A549 cells were different among the different genotypes. This is probably the result of different bioactive compounds in different genotypes. CFRA 0982 and JP 95-1-1 fruit extracts exhibited the highest antiproliferative activities on A549 cell growth. Although current literature about the origin and treatment of cancer is very complex and far from clear, many studies have documented the potential anticancer effects of flavonols and anthocyanins (Birt et al., 2001; Hou et al., 2003). Kang et al. (2003) reported that anthocyanins reduced the growth of human colon cancer cell lines HT-29 and HCT-116. Marko et al. (2004) also found that anthocyanidins significantly inhibited tumor cell growth. Strawberries are rich in anthocyanins, 


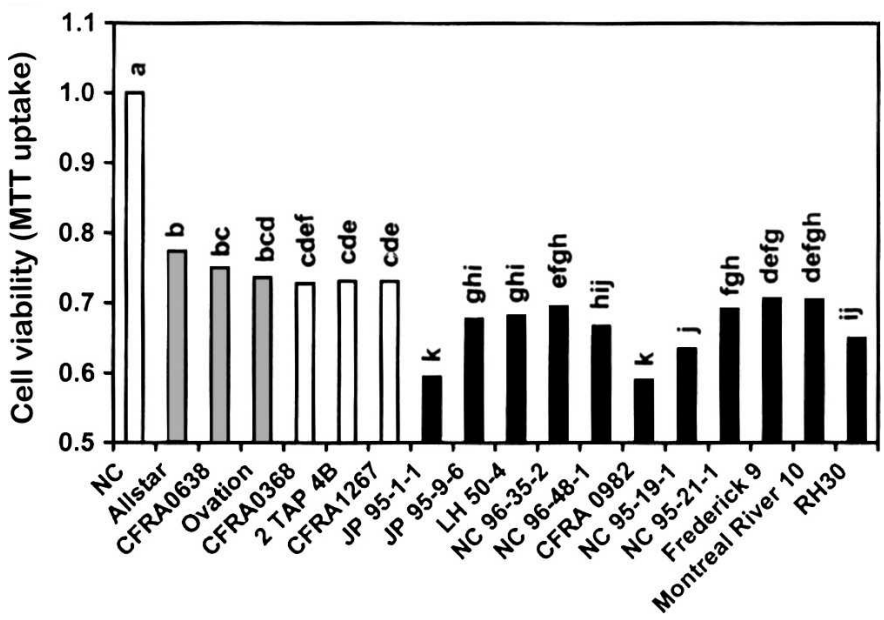

Fig. 5. Inhibition of human lung epithelial cancer A549 cells proliferation by extracts of various Fragaria (strawberry) cultivars, selections, and wild genotypes. A549 cells were plated at a density of $10^{4}$ cells/well in the 96 -well plate, cultured, differentiated, and treated with $(2.5 \mu \mathrm{g} /$ well $\mathrm{FW})$ or without extract. After $48 \mathrm{~h}$ of incubation, $10 \mu \mathrm{L}$ MTT [3-(4, 5-dimethylthiazol-2-yl)-2, 5,-diphenyl tetrazolium bromide] solution was added to each well to form formazan salt crystals, and the plates were further incubated for $4 \mathrm{~h}$. Then 100 $\mu \mathrm{L}$ solubilization solution was added and the plate was incubated overnight at $37^{\circ} \mathrm{C}$. The optical density (OD) of the wells was measured at a wavelength of $575 \mathrm{~nm}$, with a reference of $690 \mathrm{~nm}$, using an ELISA plate reader. Results were calibrated with OD measured without cell culture. Gray bars denote $F$. $\times$ ananassa, white bars denote $F$. chiloensis, solid black bars denote $F$. virginiana, and NC denotes no strawberry extract. Differences between genotypes were determined with an analysis of variance using SAS version 9.1.3 (SAS Institute, Cary, NC). The data were analyzed using the proc mixed command. Different letters indicate statistical significant differences at $P \leq 0.05$.

flavonoids, and phenolic acids (Heinonen et al., 1989). Their inhibitory activities may be the result of the synergistic combination of these polyphenols. Dietary freeze-dried strawberries were shown to effectively inhibit $N$-nitrosomethylbenzylamine-induced tumorigenesis in the rat esophagus (Evan and Vousden, 2001). Strawberry extracts have also been shown to inhibit benzo[a]pyrene-induced Syrian hamster embryo cellular transformation effectively (Xue et al., 2001). Several other kinds of fruit have also shown inhibition of hepatocellular carcinoma $\mathrm{G}_{2}\left(\mathrm{HepG}_{2}\right)$ human liver cancer cell proliferation (Carlton et al., 2001; Meyers et al., 2003, Sun et al., 2002).

Antioxidant activities were significantly correlated to antiproliferative activities on human lung epithelial cancer A549 cell growth (Table 3 and Fig. 5). It was suggested that antioxidants could prevent tumor initiation and act as a protective agent (Ding et al., 2004). Our data suggest that the activities of antioxidants and antioxidant enzymes may play an important role in the antiproliferative activity of strawberries, and the antioxidant activities are closely related with inhibition of A549 cell proliferation. The correlation data between antiproliferative effects and antioxidant activities from this study of three strawberry species further support previous finding of Wang et al. (2005). Similarly, Olsson et al. (2006) found high correlations between antiproliferation of breast cancer or prostate cancer cells and levels of ascorbate. However, Meyers et al. (2003) found no correlation between proliferation of liver cancer cells and total antioxidant content or antioxidant activity.

A multiplicity of antioxidants in strawberries, mediated by antioxidant enzymes, is beneficial because specific antioxidant molecules can be particularly effective for neutralizing specific reactive oxygen species. Of the biological free radicals, $\cdot \mathrm{OH}$ has the highest potential and is the most destructive (reactive). The radical ${ }^{1} \mathrm{O}_{2}$ has electrons in an excited state that react destructively with biomolecules containing double bonds. Anything that boosts the immune system is protective against cancer, but antioxidants have an additional anticarcinogenic effect through protection against DNA damage.

Although fruit extracts from all the tested strawberry genotypes inhibited proliferation of A594 cancer cells, fruit extracts from seven $F$. virginiana genotypes showed significantly

Table 3. Correlation coefficients $\left(R^{2}\right)$ among A549 human epithelial lung cancer cell proliferation, antioxidant activities against free radicals, and activities of antioxidant enzymes and nonenzyme components from fruit extracts of three species of strawberry (Fragaria virginiana, F. chiloensis, and F. ×ananassa).

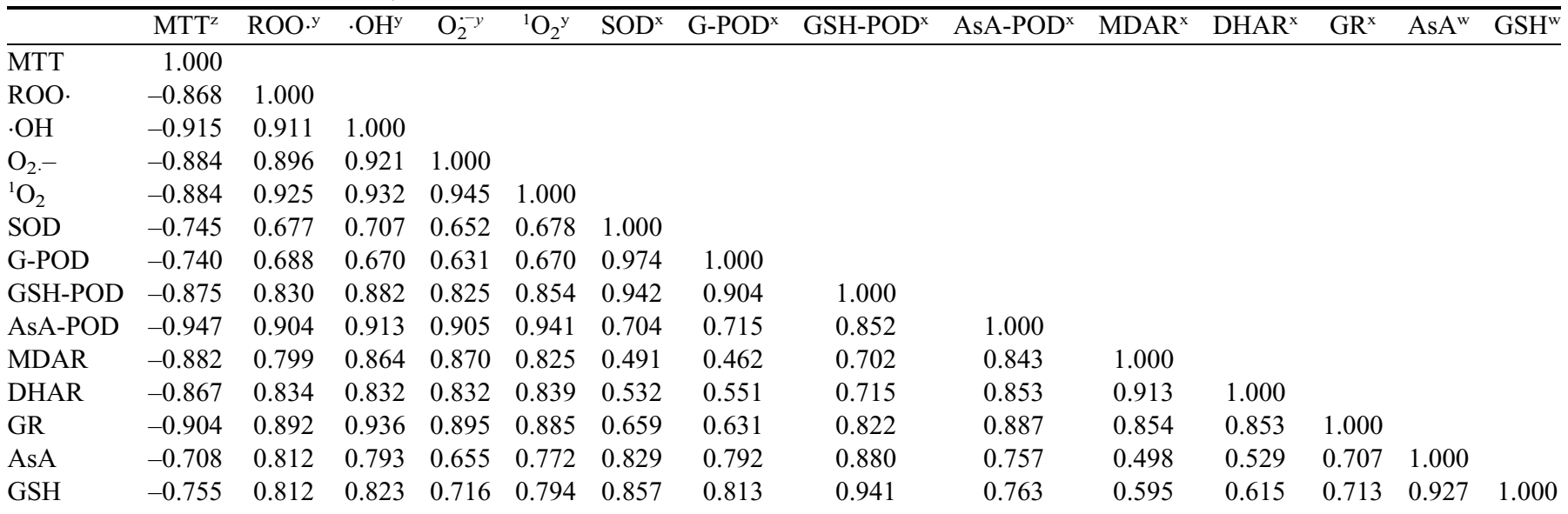

${ }^{\mathrm{z}}$ Cancer cell proliferation [MTT or 3-(4, 5-dimethylthiazol-2-yl)-2, 5,-diphenyl tetrazolium bromide] refers to the portion of cancer cell growth in comparison with growth when no strawberry fruit extract was added (1.00).

${ }^{y}$ Free radicals: peroxyl radicals $(\mathrm{ROO} \cdot)$, hydroxyl radicals $(\cdot \mathrm{OH})$, superoxide radicals $\left(\mathrm{O}_{2}^{-}\right)$, singlet oxygen $\left({ }^{1} \mathrm{O}_{2}\right)$.

${ }^{x}$ Antioxidant enzymes: superoxide dismutase (SOD), guaiacol peroxidase (G-POD), glutathione-peroxidase (GSH-POD), ascorbate peroxidase (AsA-POD), monodehydroascorbate reductase (MDAR), dehydroascorbate reductase (DHAR), and glutathione reductase (GR).

wAntioxidant nonenzyme components: ascorbic acid (AsA) and glutathione (GSH).

$R^{2}$ values were calculated using Excel 2003 (Microsoft Corp., Redmond, WA). 
greater antiproliferative effects than any of the $F$. ×ananassa or $F$. chiloensis genotypes. These genotypes, CFRA 0982, JP 951-1, NC 95-19-1, RH 30, NC 96-48-1, JP 95-9-6, and LH 50-4, may be especially useful in developing cultivars with greater anticancer potential. Of these genotypes, CFRA 0982, JP 951-1, NC 95-19-1, and RH 30 were found to be higher in antioxidant capacity (ORAC), total anthocyanins, and total phenolics than the cultivar Ovation (S.Y. Wang and K.S. Lewers, unpublished data).

The individual wild accessions highest in anticancer properties have other traits valued by strawberry breeders. NC 9519-1 and JP 95-1-1 are valued as potential sources of resistance to anthracnose crown rot incited by Colletotrichum fragariae A.N. Brooks (K.S. Lewers, W.W. Turechek, S.C. Hokanson, J.L. Maas, J.F. Hancock, S. Serçe, and B.J. Smith, unpublished data). JP 95-1-1 is also resistant to crown rot incited by $C$. gloeosporioides (Penz.) Penz. \& Sacc. in Penz. [teleomorph Glomerella cingulata (Stoneman) Spauld. \& H. Schrenk] (K.S. Lewers, W.W. Turechek, S.C. Hokanson, J.L. Maas, J.F. Hancock, S. Serçe, and B.J. Smith, unpublished data) and to both the northern root knot nematode (Meloidogyne hapla Chitwood) and the root lesion nematode [Pratyenchus penetrans (Cobb) Filipjev \& Shuurmans Stekhoven] (Pinkerton and Finn, 2005). NC95-19-1, a female, is also resistant to the root knot nematode (Pinkerton and Finn, 2005) and leaf scorch (Diplocarpon earlianum Ellis \& Everh.); tolerant to leaf blight [Phomopsis obscurans (Ellis \& Everh.) Sutton] and powdery mildew [Sphaerotheca macularis (Wallr.:Fr.) Jacz. f.sp. fragariae Peries] (Hancock et al., 2001a, b, 2002); and has very good flavor (unpublished data). RH 30 is valued because it has multiple flowering cycles in a year (Hancock et al., 2001b), and is resistant to root knot nematode (Pinkerton and Finn, 2005), black root rot incited by unknown pathogens in Minnesota, leaf scorch, and leaf spot incited by Mycosphaerella fragariae (Tul.) Lindau (Hancock et al., 2001a).

CFRA 0982, displayed more health-promoting properties than all other genotypes tested. CFRA 0982 has other characteristics that make it a potentially valuable parent, including superior flavor that it passes to first-generation progeny (unpublished data) and multiple flowering cycles (Hancock et al., 2001b). CFRA 0982 is the only member of $F$. virginiana ssp. glauca tested in this study. It also is one of the few members of the glauca subspecies from the East Coast (in this case, the state of Maine). However, it is not included in the "supercore" core subset described by Hancock et al. (2002). This core subset includes four $F$. virginiana ssp. glauca representatives from the western United States and one from the Canadian province of Quebec. It may be useful to expand evaluation of wild strawberry genotypes beyond the core subset in addition to acquiring more representatives of East Coast $F$. virginiana ssp. glauca.

In conclusion, this study suggests that activities of antioxidants and antioxidant enzymes in strawberries are potential ingredients for cancer prevention. Our results also suggest that strawberries can inhibit human lung epithelial cancer A549 cell population growth. Different strawberry genotypes had different levels of antioxidant capacity, antioxidant enzyme activity, nonenzyme components, and antiproliferative activities on A549 cells, and the correlations between all of these measures were positive and high. Therefore, the inhibition of cancer cell proliferation may be the result of the synergistic combination of multiple polyphenols found in the berries. Dietary intake of strawberries with high antioxidant capacity will have the potential to reduce cancer risk and other diseases. This study clearly shows the potential value of wild strawberry accessions in the development of strawberry cultivars with improved health-promoting qualities.

\section{Literature Cited}

Agadir, A., G. Chen, F. Bost, Y. Li, D. Mercola, and X. Zhang. 1999. Differential effect of retinoic acid on growth regulation by phorbol ester in human cancer cell lines. J. Biol. Chem. 274:29779-29785.

Amako, K., G.X. Chen, and K. Asada. 1994. Separate assay specific for ascorbate peroxidase and guaiacol peroxidase and for the chloroplastic and cytosolic isozymes of ascorbate peroxidase in plants. Plant Cell Physiol. 35:497-504.

Angel, P. and M. Karin. 1991. The role of jun, Fos and the AP-1 complex in cell-proliferation and transformation. Biochim. Biophys. Acta 1072:129-157.

Arakawa, N., K. Tsutsumi, N.G. Sanceda, T. Kurata, and C. Inagaki. 1981. A rapid and sensitive method for the determination of ascorbic acid using 4,7-diphenyl-1,10 phenanthrolene. Agr. Biol. Chem. 45: $1289-1290$.

Asada, K. 1992. Ascorbate peroxidase: A hydrogen peroxide-scavenging enzyme in plants. Physiol. Plant. 85:235-241.

Baldwin A.S.,, Jr. 1996. The NF-kappa B and I kappa B proteins: New discoveries and insights. Annu. Rev. Immunol. 14:649-683.

Birt, D.F., S. Hendrich, and W.Q. Wang. 2001. Dietary agents in cancer prevention: Flavonoids and isoflavonoids. Pharmacol. Ther. 90:157-177.

Black, B.L., J.M. Enns, and S.C. Hokanson. 2002. A comparison of temperate-climate strawberry production systems using eastern genotypes. HortTechnology 12:670-675.

Blum, J. and I. Fridovich. 1985. Inactivation of glutathione peroxidase by superoxide radical. Arch. Biochem. Biophys. 240:500-508.

Bode, A.M. and Z. Dong. 2000. Signal transduction pathways: Targets for chemoprevention of skin cancer. Lancet Oncol. 1:181-188.

Bradford, M.M. 1976. A rapid and sensitive method for the quantitation of microgram quantities of protein utilizing the principle of protein-dye binding. Anal. Biochem. 72:248-254.

Carlton, P.S., L.A. Kresty, J.C. Siglin, M.A. Morse, J. Lu, C. Morgan, and G.D. Stoner. 2001. Inhibition of $N$-nitrosomethylbenzylamineinduced tumorigenesis in the rat esophagus by dietary freeze-dried strawberries. Carcinogenesis 3:441-446.

Castillo, F.J. and H. Greppin. 1988. Extracellular ascorbic acid and enzyme activities related to ascorbic acid metabolism in Sedum album L. leaves after ozone exposure. Environ. Exp. Bot. 28:232-233.

Chakraborty, N. and B.C. Tripathy. 1992. Involvement of singlet oxygen in 5-aminolevulinic acid-induced photodynamic damage of cucumber (Cucumis sativus L.) chloroplasts. Plant Physiol. 98:7-11.

Chaudiere, J. and R. Ferrari-Iliou. 1999. Intracellular antioxidants: From chemical to biochemical mechanisms. Food Chem. Toxicol. 37:949-962.

Darrow, G.M. 1966. The strawberry: History, breeding and physiology. Holt, Rinehart and Winston, New York.

Dhar, A., M.R. Young, and N.H. Colburn. 2002. The role of AP-1, NFkappaB and ROS/NOS in skin carcinogenesis: The JB6 model is predictive. Mol. Cell. Biochem. 234-235:185-193.

Ding, M., Y. Lu, L.L. Bowman, C. Huang, S. Leonard, L. Wang, V. Vallyathan, V. Castranova, and X. Shi. 2004. Inhibition of AP-1 and neoplastic transformation by fresh apple peel extract. J. Biol. Chem. 279:10670-10676.

Dong, Z., C. Huang, R.E. Brown, and W.Y. Ma. 1997a. Inhibition of activator protein 1 activity and neoplastic transformation by aspirin. J. Biol. Chem. 272:9962-9970.

Dong, Z., W. Ma, C. Huang, and C.S. Yang. 1997b. Inhibition of tumor promoter-induced activator protein 1 activation and cell transformation by tea polyphenols, (-)-epigallocatechin gallate, and theaflavins. Cancer Res. 57:4414-4419. 
Evan, G.I. and K.H. Vousden. 2001. Proliferation, cell cycle and apoptosis in cancer. Nature 411:342-348.

Frei, B., R. Stocker, and B.N. Ames. 1992. Small molecule antioxidant defenses in human extracellular fluids, p. 23-28, 31-35, 37. In: J.G. Scandalios (ed.). Molecular biology of free radical scavenging systems. Cold Spring Harbor Laboratory Press, Cold Spring Harbor, NY.

Fridovich, I. 1986. Superoxide dismutase. Adv. Enzymol. 58:62-67. Gossett, D.R., S.W. Banks, E.P. Millhollon, and M.C. Lucas. 1996. Antioxidant response to $\mathrm{NaCl}$-stress in a control and an $\mathrm{NaCl}$-tolerant cotton cell line grown in the presence of paraquat, buthioninsulfoximine, and exogenous glutathione. Plant Physiol. 112:803-806.

Halliwell, B. and J.M.C. Gutteridge. 1989. Free radicals in biology and medicine. 2nd ed. Clarendon Press, Oxford, UK.

Hancock, J.F., P.W. Callow, A. Dale, J.J. Luby, C.E. Finn, S.C. Hokanson, and K.E. Hummer. 2001a. From the Andes to the Rockies: Native strawberry collection and utilization. HortScience 36:221-225.

Hancock, J.F., C.A. Finn, S.C. Hokanson, J.J. Luby, B.L. Goulart, K. Demchak, P.W. Callow, S. Serçe, A.M.C. Schilder, and K.E. Hummer. 2001b. A multistate comparison of native octoploid strawberries from North and South America. J. Amer. Soc. Hort. Sci. 126:579-586.

Hancock, J.F., S.C. Hokanson, C.E. Finn, and K.E. Hummer. 2002. Introducing a supercore collection of wild octoploid strawberries. Acta Hort. 567:77-79.

Heinonen, I.M., A.S. Meyer, and E.N. Frankel. 1989. Antioxidant activity of berry phenolics on human low-density lipoprotein and liposome oxidation. J. Agr. Food Chem. 46:4107-4112.

Hong, W.K. and M.B. Sporn. 1997. Recent advances in chemoprevention of cancer. Science 278:1073-1077.

Hossain, M.A. and K. Asada. 1997. Monodehydroascorbate reductase from cucumber is a flavin adenine dinucleotide enzyme. J. Biol. Chem. 260:12920-12928.

Hou, D.X., K. Kai, J.J. Li, S. Lin, N. Terahara, M. Wakamatsu, M. Fujii, M.R. Young, and N. Colburn. 2004. Anthocyanidins inhibit activator protein 1 activity and cell transformation: Structureactivity relationship and molecular mechanisms. Carcinogenesis 25:29-36.

Hou, D.X., T. Ose, S.G. Lin, K. Harazoro, I. Imamura, M. Kubo, T. Uto, N. Terahara, M. Yoshimoto, and M. Fuji. 2003. Anthocyanidins induce apoptosis in human promyelocytic leukemia cells: Structureactivity relationship and mechanisms involved. Int. J. Oncol. 23: 705-712.

Huang, D., B. Ou, M. Hampsch-Woodill, J.A. Flanagan, and R.L. Prior. 2002. High-throughput assay of oxygen radical absorbance capacity (ORAC) using a multichannel liquid handling system coupled with a microplate fluorescence reader in 96-well format. J. Agr. Food Chem. 50:4437-4444.

Hsu, T.C., M.R. Young, J. Cmarik, and N.H. Colburn. 2000. Activator protein 1 (AP-1)-and nuclear factor kappaB (NF-kappaB)-dependent transcriptional events in carcinogenesis. Free Radic. Biol. Med. 28:1338-1348.

Kang, S.Y., N.P. Seeram, M.G. Nair, and L.D. Bourquin. 2003. Tart cherry anthocyanins inhibit tumor development in Apc (Min) mice and reduce proliferation of human colon cancer cells. Cancer Lett. 194:13-19.

Kosower, N.S. and E.M. Kosower. 1978. The glutathione status of cells. Int. Rev. Cytol. 54:109-160.

Lewers, K.S., J.M. Enns, S.Y. Wang, J.L. Maas, G.J. Galletta, S.C. Hokanson, J.R. Clark, K. Demchak, R.C. Funt, S.A. Garrison, G.L. Jelenkovic, G.R. Nonnecke, P.R. Probasco, B.J. Smith, B.R. Smith, and C.A. Weber. 2004. 'Ovation' strawberry. HortScience 39:1785-1788.

Marko, D., N. Puppel, Z. Tjaden, S. Jakobs, and G. Pahlke. 2004. The substitution pattern of anthocyanidins affects different cellular signaling cascades regulating cell proliferation. Mol. Nutr. Food Res. 48:318-325.
McCord, J.M. 1979. Superoxide dismutases: Occurrence, structure, function and evolution, p. 1-21. In: M. Rattazzi, J. Scandalios, and G.S. Whitt (eds.). Isozyme: Current topics in biological and medical research, vol. 3. Liss, New York.

Meyers, K.J., C.B. Watkins, M.P. Pritts, and R.H. Liu. 2003. Antioxidant and antiproliferative activities of strawberries. J. Agr. Food Chem. 51:6887-6892.

Morel, J.B. and J.L. Dangl. 1997. The hypersensitive response and the induction of cell death in plants. Cell Death Differ. 4:671-683.

Mosmann, T. 1983. Rapid colorimetric assay for cellular growth and survival: Application to proliferation and cyto-toxicity assays. J. Immunol. Methods 65:55-63.

Nakagawara, S. and S. Sagisaka. 1984. Increase in enzyme activities related to ascorbate metabolism during cold acclimation of poplar twigs. Plant Cell Physiol. 25:899-906.

Olsson, M.E., C.S. Andersson, S. Oredsson, R.H. Berglund, and K.E. Gustavsson. 2006. Antioxidant levels and inhibition of cancer cell proliferation in vitro by extracts from organically and conventionally cultivated strawberries. J. Agr. Food Chem. 54:1248-1255.

Pinkerton, J. and C.E. Finn. 2005. Responses of strawberry species and cultivars to the root-lesion and northern root-knot nematodes. HortScience 40:33-38.

Richmond, R., B. Halliwell, J. Chauhan, and A. Darbre. 1981. Superoxide-dependent formation of hydroxyl radicals: Detection of hydroxyl radicals by the hydroxylation of aromatic compound. Anal. Biochem. 118:328-330.

Satué-Gracia, M.T., I.M. Heinonen, and E.N. Frankel. 1997. Anthocyanins as antioxidants on human low-density lipoprotein and lecithin-liposome systems. J. Agr. Food Chem. 45:3362-3367.

Schulze-Osthoff, K., D. Ferrari, K. Riehemann, and S. Wesselborg. 1997. Regulation of NF-kappa B activation by MAP kinase cascades. Immunobiology 198:35-49.

Shigeoka, S., Y. Nakano, and S. Kitaoka. 1980. Metabolism of hydrogen peroxide in Euglena gracilis $\mathrm{z}$ by L-ascorbic acid peroxidase. Biochem. J. 186:377-380.

Smith, I.K., T.L. Vierheller, and C.A. Thorne. 1988. Assay of glutathione reductase in crude tissue homogenates using 5,5-dithiobis (2-nitrobenzoic acid). Anal. Biochem. 175:408-413.

Sun, J., Y.F. Chu, X. Wu, and R.H. Liu. 2002. Antioxidant and antiproliferation activities of fruits. J. Agr. Food Chem. 50:7449-7454.

Tanaka, K. 1994. Tolerance to herbicides and air pollutants, p. 373375. In: C.H. Foyer and P.M. Mullineaux (eds.). Causes of photooxidative stress amelioration of defense systems in plants. CRC Press, Boca Raton, FL.

Tappel, A.L. 1978. Glutathione peroxidase and hydroperoxidase. Methods Enzymol. 52c:506-513.

Velioglu, Y.S., G. Mazza, L. Gao, and B.D. Oomah. 1998. Antioxidant activity and total phenolics in selected fruits, vegetables, and grain products. J. Agr. Food Chem. 46:4113-4117.

Wang, S.Y., R. Feng, Y. Lu, L. Bowman, and M. Ding. 2005. Inhibitory effect on activator protein-1, nuclear factor-kappa B, and cell transformation by extracts of strawberries (Fragaria ×ananassa Duch.). J. Agr. Food Chem. 53:4187-4193.

Wang, S.Y. and H.J. Jiao. 2000. Scavenging capacity of berry crops on superoxide radicals, hydrogen peroxide, hydroxyl radicals, and singlet oxygen. J. Agr. Food Chem. 48:5677-5684.

Wang, S.Y., H.J. Jiao, and M. Faust. 1991. Changes in superoxide dismutase activity during thidiazuron-induced lateral budbreak of apple. HortScience 26:1202-1204.

Wang, S.Y. and H.S. Lin. 2000. Antioxidant activity in fruits and leaves of blackberry, raspberry, and strawberry varies with cultivar and developmental stage. J. Agr. Food Chem. 48:140-146.

Xue, H., R.M. Aziz, N. Sun, J.M. Cassady, L.M. Kamendulis, Y. Xu, G.D. Stoner, and J.E. Klaunig. 2001. Inhibition of cellular transformation by berry extracts. Carcinogenesis (London) 22:351-356.

Ziegler, D.M. 1985. Role of reversible oxidation-reduction of enzyme thiols-disulfides in metabolic regulation. Annu. Rev. Biochem. 54:305-329. 